\title{
O Nepotismo no Brasil: uma explicação institucionalista a partir das interpretações de Raymundo Faoro e Sérgio Buarque de Holanda
}

Herton Castiglioni Lopes*

\begin{abstract}
"E pois que, Senhor, é certo que tanto neste cargo que levo como em qualquer coisa que de vosso serviço for, Vossa alteza há de ser de mim muito bem servida, a Ela peço que, por me fazer singular mercê, manda vir da ilha de São Tomé a Jorge Osório, meu Genro - O que d'Ela receberei em muita mercê." (Caminha, Maio de 1500).
\end{abstract}

\begin{abstract}
"A sociedade brasileira não sabe separar o público do privado (...) Tanto a sociedade civil como os próprios servidores legitimaram o nepotismo" (Prof. Caldas da UnB ao comentar pesquisa sobre Ética Pública em 2008)
\end{abstract}

Resumo: Este trabalho tem o objetivo de explicar o nepotismo a partir da História do Brasil. Em especial, utiliza-se das obras de Raymundo Faoro e Sérgio Buarque de Holanda e os respectivos conceitos de "Estamento Burocrático" e "Homem Cordial" dos autores. A persistência do problema no Brasil contemporâneo é explicada de acordo com a visão institucionalista, que esclarece a razão de permanência de algumas instituições, mesmo anacrônicas. As conclusões são de que a prática de favorecimento a parentes e amigos de governantes é originária de nossos colonizadores e consolidou-se como uma instituição informal de difícil eliminação.

Palavras-Chave: Nepotismo. Raymundo Faoro. Sérgio Buarque de Holanda. Instituições.

\section{Nepotism in Brazil: an institutionalist explanation from the interpretation of Raymundo Faoro and Sérgio Buarque de Holanda}

\begin{abstract}
This paper aims to explain nepotism up from the Brazilian History. We mainly use Raymundo Faoro's and Sérgio Buarque de Holanda's works and their concepts of "Bureaucratic Social Class" and "Courteous Man". The persistence of this problem in Brazil nowadays is explained by the institutionalist view, which explains the reason for the permanence of some institutions, even though being anachronic. The conclusions are that the practice of favoring parents and friends of executives in government comes from our colonizers and it consolidated with an institution that is both informal and hard to eliminate.
\end{abstract}

Keywords Nepotism. Raymundo Faoro. Sérgio Buarque de Holanda. Institutions.

Classificação JEL: N0; B15; B52.

\footnotetext{
* Doutor em Economia pela UFRGS. Professor Adjunto da UFFS. E-mail: herton.lopes@uffs.edu.br
} 


\section{Introdução}

Este trabalho tem o objetivo de analisar o nepotismo ${ }^{1}$ no Brasil de acordo com as interpretações de Raymundo Faoro e Sérgio Buarque de Holanda, utilizando-se de um enfoque institucionalista para explicar o problema. Embora condenado pela opinião pública e pela própria constituição federal, o favorecimento a parentes de quem ocupa cargos públicos merece maior atenção dos estudiosos e autoridades que se interessam sobre $\mathrm{o}$ assunto. Contemporaneamente, a persistência do nepotismo é analisada a partir do significativo número de cargos de confiança presentes nas três esferas do governo. Conforme se demonstra na sequencia, o número de cargos comissionados é elevado comparativamente a outros países e abre espaço para nomeação de parentes e amigos para o exercício de atividades administrativas junto à esfera pública.

Embora considerado um problema de gestão pública, as tentativas para eliminar o nepotismo até então não foram bem sucedidas e observe-se que elas nada têm de recentes. A Constituição de 1934 já determinava que o ingresso no cargo público deveria efetivar-se apenas mediante a realização de concurso, garantindo o acesso ao funcionalismo estatal mediante o mérito dos candidatos. As constituições que viriam na sequência repetiram o texto que pouca aplicação prática recebeu.

Frente ao problema e à sua difícil eliminação, admite-se que a questão tenha raízes mais profundas do que parece à primeira vista. A explicação para a persistência do nepotismo deve ser buscada no contexto histórico de formação da nossa sociedade, em especial relacionada à nossa colonização. Dessa forma, ao unirem-se as interpretações de Raymundo Faoro em "Os Donos do Poder" com a de Sérgio Buarque em "Raízes do Brasil" — respectivamente com os conceitos de "Estamento Burocrático" e de "Homem Cordial" — e as correntes institucionalistas, seja o chamado "antigo" ou "novo" institucionalismo, encontra-se a explicação para a persistência desse mal que acomete nossa sociedade.

Além desta introdução, o trabalho apresenta-se assim dividido: a segunda seção traz a interpretação de Faoro, em especial relacionada aos aspectos que podem ser utilizados para explicar o nepotismo (formação do Estado e Estamento Burocrático em Portugal e sua consolidação no Brasil). Em seguida, a terceira seção, mostra a avaliação histórica de Sérgio Buarque de Holanda e o conceito de "Homem Cordial", que se define como comportamento

\footnotetext{
${ }^{1}$ Segundo o dicionário Aurélio, Nepotismo (de nepote + ismo) se refere à autoridade que os sobrinhos e outros parentes do papa exerciam na administração eclesiástica. Uma definição mais adequada ao trabalho sugere que se trata de uma política de favorecimento a parentes ou amigos de quem ocupa cargo público.
} 
característico dos brasileiros. A quarta ocupa-se do institucionalismo, especificamente do chamado "antigo" e "novo" institucionalismo, ficando evidente sua eficiência na explicação do problema. Na quinta seção, procura-se demonstrar como as instituições da América Portuguesa se transmitem ao Brasil. Em seguida, são apresentadas as tentativas (constitucionais) de eliminação do nepotismo e dados sobre o número de cargos comissionados no Brasil, que abrem possibilidades para persistência do problema (seção 6). A sétima seção mostra a convergência entre o pensamento de Raymundo Faoro, de Sérgio Buarque de Holanda e os institucionalistas na explicação do nepotismo. Em seguida, são formuladas as considerações finais.

\section{Raymundo Faoro e os "donos do poder"}

Raymundo Faoro foi Advogado, Jurista e Escritor. Nascido em Vacaria no Rio Grande do Sul a 27 de abril de 1925 e falecido em 15 de Maio de 2003, foi imortalizado em 2000 ao ser eleito para a Academia Brasileira de Letras. Faoro é considerado um de nossos grandes pensadores e sua obra "Os Donos do Poder: formação do patronato político brasileiro" consolidada como uma das grandes interpretações do Brasil. Nessa obra, escrita em 1958, Faoro analisa, como o próprio título sugere, a formação do patronato político brasileiro, buscando suas origens na sociedade luso-brasileira. A interpretação do autor, portanto, apresenta grande utilidade na explicação do nepotismo em nossa sociedade. A seguir, procura-se apresentar a origem do problema, que está relacionada à nossa colonização e a formação do "Estamento Burocrático" em Portugal. Em seguida, passa-se para a análise do Brasil e a consolidação do Estamento em nosso País.

\subsection{Estado e Estamento Burocrático na sociedade portuguesa}

Nas descrições de Faoro (2001) sobre as características dos nossos colonizadores e formação do Estado português, é possível encontrar explicações para diversas particularidades do Brasil contemporâneo. Tratando-se da gestão pública, o autor ilustra como a formação de 
um Estado patrimonialista ${ }^{2}$ em Portugal $^{3}$, com dificuldades de separação entre o Público e o Privado, facilita o desenvolvimento de diversas mazelas econômicas e sociais, entre elas o nepotismo ${ }^{4}$.

Já nos primeiros dois séculos de formação do Reino de Portugal, é possível constatar que as atividades públicas acabavam exercidas em benefício pessoal em vez de serem utilizadas de forma racional e visando ao bem-estar da sociedade. Nesse período, a imensa propriedade rural da Coroa se confundia com o domínio da casa real e o produto dessa propriedade era livremente aplicado para o bem coletivo ou para as necessidades pessoais do rei: "A propriedade do rei suas terras e seus tesouros - se confunde nos seus aspectos público e particular. Rendas e despesas se aplicam, sem discriminação normativa prévia, nos gastos de família ou em obras e serviços de utilidade geral" (FAORO, 2001, p. 23).

O típico Estado patrimonialista, além de não reconhecer a separação entre o público e privado, mantém relações características e diferenciadas com seu quadro administrativo. Como camada dirigente desse Estado, forma-se o Estamento Burocrático ${ }^{5}$. Trata-se de um conjunto de pessoas que comanda a Economia junto ao governante. Em Portugal, já na ascensão do primeiro rei da dinastia de Avis (1385-1580), Dom João I, esse Estamento se avoluma,

\footnotetext{
${ }^{2}$ A concepção de Estado patrimonialista em Faoro resulta de Weber (2005). Para o autor, o poder é legitimado por três tipos de dominação, também características do Estado: a dominação racional-legal, a carismática e a tradicional. A dominação racional-legal está relacionada ao fato de que qualquer direito pode ser criado e modificado por um estatuto elaborado corretamente. Nesse caso, a burocracia é o tipo mais puro de dominação e o poder ou autoridade é legalmente estabelecido. Na carismática, a dominação é garantida graças à devoção afetiva dos subordinados ao superior, que ocorre em função do carisma (dotes sobrenaturais) e também devido a faculdades mágicas, revelações ou heroísmo, poder intelectual ou de oratória. A dominação tradicional, por sua vez, é resultado da fidelidade, assentada nas crenças de superioridade do senhor em relação aos seus súditos. Esse tipo de dominação pode ser dividido em feudal e patrimonial, estando essa última alicerçada no Patriarcalismo e que, na concepção de Faoro (2001), explica a fundamentação do poder político em algumas sociedades modernas. Convém, contudo, reforçar que os três tipos de dominação são os tipos ideais ou puros, sendo, na realidade, dificilmente observável um único tipo de dominação.

${ }^{3}$ A consolidação do Estado português é resultado da união de aspectos presentes no direito romano, calcado nas tradições eclesiásticas, em certo grau renovado pelos juristas da Escola de Bolonha. Desde sua formação, essa organização afasta-se do Estado racional, que se originaria com a consolidação das relações capitalistas na Europa (FAORO, 2001). Para Carvalho (1980), o Estado português é decorrência do tipo de revolução burguesa vivenciado pelo país, que determinou não somente a formação da elite, mas as características que assumem o Estado diante de acontecimentos políticos e econômicos. No pensamento do autor, o Estado assume um papel muito menos importante e burocrático nos países em que se consolida rapidamente a revolução burguesa (caso típico da Inglaterra), enquanto assume caráter diferenciado nos países em que a revolução burguesa ocorre de cima para baixo (exemplo da Prússia) e nos casos de revolução burguesa abortada, como Portugal. Nesse último caso, o Estado ganha peso significativo como regulador da vida social e se torna maior a participação do funcionalismo civil e militar, assim como mais representativa se torna a elite política.

${ }^{4}$ Embora a palavra "nepotismo" não seja apresentada por Faoro (2001), quando critica as práticas de um Estado do tipo patrimonialista constata-se que o personalismo e o favorecimento a parentes e amigos estão presentes nesse tipo de Estado. Evidentemente, é o que se procura demonstrar a seguir.

${ }^{5}$ O conceito de Estamento Burocrático apresentado por Faoro (2001) é influenciado pelos três tipos ideais de Weber. Apesar disso é um conceito inovador que mescla as formas de dominação tradicional e racional legal.
} 
logicamente por motivos econômicos, pois os negócios da coroa necessitavam de uma rede de representantes que fizessem cumprir seus interesses, especialmente os ligados à Economia comercial mercantilista ${ }^{6}$. Ao redor do rei cria-se, então, um grupo de conselheiros e executores, encarregados, entre outras coisas, de assegurar a participação do governante nos negócios dos súditos. Essa é a realidade do Estado patrimonial, que sugere um quadro administrativo de caráter precocemente ministerial, encarregado de garantir os interesses do rei na sua ausência (FAORO, 2001).

Para garantir esses interesses o Estado se aparelha, amplia-se sempre que necessário e, dessa estrutura de poder, forma-se uma comunidade. O Estamento não é uma classe social, porque essa nasce de uma agregação de interesses econômicos determinados principalmente pelo mercado. É uma camada social e não econômica, embora possa apresentar-se relacionada a essa última. Constitui-se de uma comunidade formada por indivíduos conscientes de pertencerem ao mesmo grupo. São qualificados para exercer o poder e usufruir do prestígio que o mesmo proporciona. Tais grupos são característicos de locais em que as relações de mercado não dominam inteiramente a sociedade, embora seja comum a sua permanência em sociedades capitalistas. O estamento político é formado por indivíduos que possuem interesses de grupo e não raro formado hereditariamente.

Junto ao rei, livremente recrutada, uma comunidade - patronato, parceria, oligarquia, como quer que a domine a censura pública - manda, governa, dirige, orienta, determinando, não apenas formalmente, o curso da Economia e as expressões da sociedade, sociedade tolhida, impedida, amordaçada (FAORO, 2005, p.63).

Chamam a atenção nas afirmações de Faoro (2001) três considerações: $1^{\circ}$ ) os indivíduos que formam esse Estamento governam, na maioria das vezes, de acordo com seus interesses econômicos; $2^{\circ}$ ) tratam-se de pessoas nomeadas de acordo a decisão do governante. Essa nomeação não requer necessariamente que as mesmas possuam poder econômico, pois o Estamento apresenta significativa desigualdade social entre seus componentes. Basta que

\footnotetext{
${ }^{6}$ Carvalho (1980) confirma a ideia de Faoro (2001) sobre esse aspecto. Para o autor, a ascensão de Dom João I ao trono configura-se no golpe decisivo nos barões feudais, já enfraquecidos nas lutas contra os mouros. A esses nobres enfraquecidos restou buscar serviços junto ao rei ou a empresa colonial. Diferentemente do que ocorreu na Inglaterra, em que o exercício da atividade não se vinculava a preocupações materiais, em Portugal representava o sustento dos antigos nobres. Evidentemente, essa antiga nobreza acabou tendo que dividir os empregos com os juristas e magistrados que exerceram papel significativo na política portuguesa e depois brasileira. No caso específico de Portugal (assim como na Prússia) aconteceu um caso interessante de treinamento e profissionalização das elites do país. Uma verdadeira burocratização, no sentido de que elas perdiam o seu sentido de representação de classe e constituíam-se em um grupo de pessoas destinadas ao exercício do poder.
} 
apresentem certas qualidades de personalidade, ou seja, perfil próprio que os enquadre no grupo e; $3^{\circ}$ ) pode ser observada hereditariedade entre os componentes dessa comunidade. Contudo, não se observa, necessariamente, a perpetuação das mesmas famílias no poder, pois o Governo não passa necessariamente de pai para filho, mas os laços de parentesco podem estar presentes.

Diversas são as vantagens de se pertencer ao Estamento, mais restritas, no entanto, são as formas de ingresso a esse seleto grupo de pessoas. As vantagens de pertencer ao Estamento, fidalguia ou riqueza, atraem pretendentes ao funcionalismo: "a corte, povoada de senhores e embaixadores, torna-se o sítio preferido dos comerciantes, todos, porém, acotovelados com a chusma dos pretendentes - pretendentes de mercês econômicas, de cargos, capitanias e postos militares" (FAORO, 2001, p. 99).

O Estamento é "burocrático". Mas, afirma Faoro (2001), burocracia não no sentido moderno da expressão, mas referindo-se a apropriação do cargo. Essa camada se alimenta do comércio e, embora muitas vezes não sejam exatamente nobres, ocupam rapidamente o lugar da velha nobreza, adquirindo os seus costumes e consumindo improdutivamente os frutos das atividades comerciais porque este consumo lhes oferece reconhecimento social. As atividades econômicas e, portanto, o capitalismo devem ser politicamente orientados, com empresas dependentes da vontade do soberano e onde grande parte das vezes, o Estado se confunde com o empresário. "Onde há atividade econômica, lá estará o delegado do rei, o funcionário, para compartilhar suas rendas, lucros, e, mesmo incrementá-la” (FAORO, 2001, p.103). Além de serem em quantidade significativa, "estes acumulam dois, três e quatro cargos, ajudados de muitos oficiais, no cultivo do ócio, agarrando com unhas e dentes todo o comércio, a Economia inteira" (FAORO, 2004, p.102).

\subsection{O Estamento: de Portugal para o Brasil}

O Estamento Burocrático não é encontrado apenas em sociedades arcaicas. Pelo contrário, embora a descrição inicial de Faoro (2001) mostre sua formação nas origens do Estado Português, os resquícios estamentais sobrevivem vigorosamente nas sociedades capitalistas modernas. Mantém-se vivas proporcionando garantias aos seus integrantes e, onde existirem chances de ganhos econômicos, poderá se formar uma comunidade que se aproprie dessas rendas: "o fechamento da comunidade leva a apropriação de oportunidades econômicas, que desembocam, no ponto extremo, nos monopólios de atividades lucrativas e cargos públicos" (FAORO, 2001, p.62). 
Se o Estamento Burocrático esteve presente no Estado Português e pode sobreviver nas sociedades modernas, sua germinação no Brasil Colônia e perpetuação no Brasil contemporâneo é fato relevante. Essa é a interpretação de Faoro (2001), pois para o autor, o Estado português, caracterizado como patrimonialista, determinou efeitos econômicos que se prolongam no Brasil, durante o século XX e até os dias atuais. São nesses elementos históricos que devemos buscar as respostas para alguns problemas que persistem, barram nosso desenvolvimento e constrangem nossa sociedade (FAORO, 2001).

O Estado Português transmitiu suas feições ao brasileiro. Nosso Imperador se mostrou incapaz de criar um sistema político que assimilasse as velhas ideias importadas com as modernizantes (provindas da França e Inglaterra). Assim como a presença do Estamento, no Brasil Império já se observa a livre nomeação de pessoas para ocuparem os mais diversos cargos públicos, pois o Imperador sente-se autorizado a nomear e demitir livremente seus ministros (FAORO, 2001). A descrição dessa camada político-social presente no período apresenta-se muito semelhante à descrição feita para Portugal. Evidentemente, por isso, recebe a mesma denominação.

O Estamento mostra sua presença pelo fato do poder imperial ser representado por uma “camada dirigente aristocrática na sua função e nas suas origens históricas", que "fecha-se na sua perpetuidade hereditária, ao eleger os filhos e genros, com o mínimo de concessões ao sangue novo" (FAORO, 2001, p. 445). À semelhança de Portugal temos uma antinomia entre Estado e nação e uma mistura entre público e privado, pois entre as pessoas que formam o Estamento Burocrático ofertam-se jantares de confraternização e neles os empregos públicos e carreiras políticas são prometidas.

Não se trata de uma classe que se apropria do Estado e do seu mecanismo burocrático para comandar o Governo, mas é uma categorial social que manipula lealdades com o cargo público. Um segmento social que observa no Estado a possibilidade de vantagens pessoais. Procura consolidar uma carreira política mediante troca de favores e empreguismo. "Entre a carreira política e a dos empregos há uma conexão íntima e necessária, servindo o Estado como despenseiro de recursos, para o jogo interno da troca de vantagens" (FAORO, 2001, p. 447).

Quais as consequências dessa ordem burocrática Estamental no Brasil? Para Faoro, o fato inegável e fundamental "[...] será a inquieta, ardente, apaixonada caça ao emprego público" (FAORO, 2001, p.448). Só esse emprego é nobre, somente esse emprego oferece o poder. O emprego público se transforma em uma obsessão. Buscam-no não somente os letrados, mas também os proprietários. As razões para isso parecem irracionais, pois homens de recursos 
poderiam apenas aplicar suas posses de forma produtiva e auferir ganhos que dificilmente o cargo público lhes proporcionaria. Ledo engano, por mais dinheiro que ofereça, não proporciona poder, prestígio e reconhecimento, características que se somam aos benefícios monetários do emprego Estatal.

Aspecto importante mencionado por Faoro (2001) é o fato de que a camada social que forma o Estamento muda e se renova, mas como característica permanece o fato de não representar a nação. O Estamento burocrático brasileiro passa a dirigir a esfera econômica e política. No primeiro caso, as determinações desse Estamento ultrapassam o ideário liberal, passando a recomendações de políticas financeiras e monetárias, gestão direta de empresas, com regime de concessões estatais e ordenações sobre o trabalho. Junto à sociedade, o Estamento determina as possibilidades de ascensão econômica. No âmbito político, o quadro se centraliza no comando. "Grupos, classes, elites, associações tentam, lutam para fugir do abraço sufocador da ordem imposta de cima, seja pelo centrifuguismo colonial, o federalismo republicano, a autonomia do senhor de terra" (FAORO, 2001, p. 826).

Na História brasileira, seja o rei, o imperador ou o presidente, o fato é que essas figuras desempenham o papel de comandar o Estamento que se desaristocratiza e se burocratiza, passando a regular as relações sociais. O Estado se torna o polo condutor da sociedade e nele concentram-se as esperanças dos pobres e dos ricos. De Dom João a Getúlio Vargas, diz Faoro (2001, p.819), “[...] durante seis séculos uma estrutura político-social resistiu a todas as transformações fundamentais, aos desafios mais profundos, à travessia do oceano largo". Uma estrutura político social que governa para si, uma comunidade política que "[...] conduz, comanda, supervisiona os negócios, como negócios privados seus, na origem, como negócios privados depois, em linhas que se demarcam gradualmente" (FAORO, 2001, p. 819).

Da mesma forma que Faoro (2001), Sérgio Buarque de Holanda mostra uma interpretação histórica de formação de nossa sociedade útil na explicação do nepotismo, observemos a seguir os traços de pensamento do autor úteis na explicação desse fenômeno.

\section{Sérgio Buarque de Holanda e as "Raízes do Brasil"}

Sérgio Buarque de Holanda nasceu em São Paulo em 1902. Falecido em 1982, foi jornalista, sociólogo e historiador. É autor de diversas obras, entre as quais se destaca "Raízes do Brasil" que, assim como a obra de Faoro, é considerada uma das grandes interpretações do Brasil. Essa obra aborda, em um contexto histórico, a formação da sociedade e do Estado brasileiros. A partir da concepção de "Homem Cordial”, Holanda mostra a explicação de uma 
série de problemas presentes no Brasil que persistem por muito tempo. Apesar de o primeiro ensaio da obra ter sido escrito em 1936, a descrição de Holanda (1995) mostra um grau espantoso de atualidade. A seguir abordam-se os aspectos ressaltados pelo autor que são úteis na explicação do nepotismo.

\subsection{A colonização portuguesa}

À semelhança da análise de Faoro, Holanda (1995) procura interpretar o Brasil a partir de nossas origens. Aparecem em sua análise as características dos nossos colonizadores que serão capazes de explicar a origem do problema do nepotismo e de diversas outras questões que prejudicam a sociedade brasileira. Assim como se observa em Faoro (2001), a análise do autor está calcada na concepção de Estado patrimonialista, que mostra dificuldade de separação entre as esferas pública e privada, fazendo com que os governantes procurem os interesses próprios em vez de sociais. Esse problema, segundo Holanda (1995), é traço característico do comportamento português, sendo resultado da estrutura de nossa sociedade colonial, que teve sua base fora dos meios urbanos, com tradições que não foram apagadas com nossa independência ${ }^{7}$.

Nossa origem portuguesa deixou como herança uma busca incessante por posições de nobreza perante a sociedade. Ser nobre representava repulsa a qualquer tipo de trabalho manual. Desprezo pelo trabalho e verdadeira paixão pelo ganho fácil são traços que definem nossos colonizadores. Na persistência de tais características, que local mais apropriado para pessoas com esse comportamento que se alocarem como funcionários do Estado? Principalmente em um período em que o funcionalismo é visto apenas como órgão fiscalizador que, além de não desempenhar nenhum tipo de trabalho manual, representa os interesses do Governante e, aos olhos da sociedade, oferece nobreza e prestígio, o Estado patrimonialista se converte em excelente atrativo às diversas classes sociais que dele desejam beneficiar-se.

Merecem um pouco mais de reflexão os comentários Holanda (1995) sobre a precária mentalidade burguesa dos portugueses. Além do próprio atraso econômico, essa interpretação contribui para a explicação dos empregos públicos por apadrinhamento ou parentesco. Para nossos colonizadores, a ascensão econômica, por meio de atividades tipicamente comerciais, não garantia o prestígio e poder normalmente encontrado em sociedades capitalistas avançadas

\footnotetext{
${ }^{7}$ Segundo Holanda (1995), embora a civilização implantada pelos portugueses não tenha sido rigorosamente agrícola, sem dúvida, foi uma sociedade com raízes rurais. Essa realidade, segundo o autor, não se modificou significativamente até abolição.
} 
(ou em estágio de desenvolvimento). Para ascensão e prestígio, outro fator é fundamental: a fidalguia. Busca-se, assim, distinguir os indivíduos de acordo com sua origem familiar, de forma que os nobres seriam os privilegiados para ascender socialmente, e preferidos no exercício do cargo público. Contudo, embora essencial, nem sempre a fidalguia se caracteriza como um pré-requisito, pois após enriquecerem em atividades comerciais, eram comuns os casos em que simples trabalhadores conquistavam (ou compravam) títulos de nobreza, passando ao status de "nobres".

Portanto, o acesso de homens simples a esses grupos sociais "elitizados" não era completamente vedado. Mas a mentalidade lusitana, ao condenar a ética do trabalho, fazia rapidamente os "Novos Nobres" esquecerem-se de sua origem, incorporando a cultura e os costumes da nova classe: “À medida que subiam na escala social, as camadas populares deixavam de ser portadoras de sua primitiva mentalidade de classe para aderirem à dos antigos grupos dominantes" (HOLANDA, 1995, p. 112). Uma verdadeira "aversão às virtudes econômicas" porque essas classes procuram mais a glória, do que as atividades lucrativas, preferem mais vínculos pessoais e diretos que a racionalização econômica. Da mesma forma, preferem um cargo público, o prestígio e as relações que o mesmo oferece, em vez de manterem-se nas atividades capitalistas. Optam, portanto, por unir-se a uma burguesia que controla o Estado em vez de se manterem presos pelos antigos valores que, muitas vezes, permitiram seu ingresso nessas mesmas classes.

As relações pessoais são um traço característico dos colonizadores, herdados por nós brasileiros. Holanda (1995) mostra que essas relações e a fácil adaptação dos portugueses a ambientes, por vezes hostis, é um dos fatores que explica o seu êxito como colonizadores. Está nesse comportamento a origem do "Homem Cordial", que vai ser fundamental na explicação das relações de poder presentes no Estado português, transferidas ao brasileiro. São relações que se transferem do setor privado ao setor público. No setor privado, o melhor antes de fazer um cliente é fazer um amigo ${ }^{8}$ e, no setor público, não é concebível que um funcionário deixe de "prestar a amigos e parentes favores dependentes de tal função" (HOLANDA, 1995, p. 134).

\footnotetext{
${ }^{8}$ Holanda (1995) ilustra a anedota comentada por André Siegfried sobre um negociante da Filadélfia que verificou ser necessário, para conquistar um freguês no Brasil ou Argentina, iniciar fazendo dele um amigo.
} 


\section{2 "Homem Cordial”, relações pessoais e nepotismo}

A concepção de "Homem Cordial" - muito útil para explicar o nepotismo - está relacionada à dificuldade dos brasileiros de separar os traços familiares e diretos dos traços racionais e impessoais, que caracterizam a moderna mentalidade de mercado e estatal. Para Holanda (1995), essa dificuldade é decorrência da rápida urbanização pela qual passou nossa sociedade. Ou seja, os detentores de posições públicas, criados em ambientes em que predominavam as relações familiares ${ }^{9}$, ao serem retirados de suas famílias e enviados às escolas com formação mais rígida e com relações diferenciadas das quais estavam acostumados, não conseguem superar facilmente as antigas relações sociais: "[...] estereotipada por longos anos de vida rural, a mentalidade da casa-grande invadiu assim as cidades e conquistou todas as profissões, sem exclusão das mais humildes" (HOLANDA, 1995, p. 87).

No Brasil, a fidalguia ou as relações familiares se transforma no fator fundamental para reconhecimento social. Forma-se uma sociedade patriarcal, tipificada no senhor de engenho que agrega junto à sua propriedade parentes de diversos graus, subordinados à sua vontade. Como exemplifica Holanda (1995) tudo se fazia consoante a vontade do senhor de engenho, vontade por vezes caprichosa e despótica. O engenho, por sua vez, era um organismo completo, "bastava a si mesmo". Nele se encontrava a capela para rezar missas, escolas, criações, atividades de caça, pesca etc. Tipo de organização familiar que se assemelha às de origem ibérica e que sobreviveu por diversas gerações. O círculo é ainda ampliado pelos escravos, diversas vezes com relações muito próximas de seus senhores e por outros agregados. Esse tipo de organização fecha-se em si e os laços afetivos são a base de organização não só familiar, mas também econômica.

O tipo de organização familiar descrito por Holanda (1995) extrapola das relações privadas para o setor público. Com o declínio da grande lavoura e ascensão dos centros urbanos, fatos acelerados pela chegada da corte portuguesa em 1808 e pela independência, os senhores rurais necessitaram de estabelecer-se em outras ocupações. Mas, tal como nossa tradição recomenda, não é papel de homens nobres, como se consideravam, adequarem-se a ocupações laboriosas. Assim, quais as ocupações mais justas para esses nobres homens, de tão vasta

\footnotetext{
${ }^{9}$ Uma descrição mais aprofundada sobre as relações familiares no Brasil colônia pode ser encontrada em "Casa Grande \& Senzala” de Gilberto Freire. Assim como as obras de Raymundo Faoro e Sérgio Buarque de Holanda, é considerada uma das grandes interpretações do Brasil, de forma que omitir referência ao autor que destaca a contribuição da Casa Grande e da Senzala na formação sociocultural brasileira seria, no mínimo, insensatez. Nessa obra, Gilberto Freire mostra como a estrutura da casa grande, que abrigava escravos, parentes, filhos etc. era dominada pelo senhor de terra. Assim como é possível verificar como essa estrutura daria origem ao modo de organização política e social presente no País: o patriarcalismo.
} 
inteligência que isso bastaria para promover o seu enriquecimento? Evidentemente basta dirigirem-se ao Estado.

À semelhança da família patriarcal, vão-se consolidar as relações sociais do Brasil. A vida política nacional será um reflexo dessas relações, que invadem não somente a esfera privada. "A família patriarcal fornece, assim, o grande modelo por onde se hão de calcar, na vida política, as relações entre governantes e governados, entre monarcas e súditos" (HOLANDA, 1995, p. 85).

Um tipo de vida política que diverge do moderno Estado burocrático. O que diferencia esse último, diz Holanda (1995) citando Max Weber, é que nele observam-se dois tipos de funcionários, o "patrimonial" para o qual a gestão pública se apresenta como interesse particular: "[...] as funções, os empregos e os benefícios que deles aufere relacionam-se a direitos pessoais do funcionário e não a interesses objetivos" e; o Burocrático, com relações em que "[...] prevalecem a especialização das funções e o esforço para se assegurarem garantias jurídicas dos cidadãos" (HOLANDA, 1995, p.146). Predomina, evidentemente, esse último aspecto. No entanto, embora o Estado patrimonialista assuma traços burocráticos, em essência, continua patrimonial.

Holanda (1995) vai além e afirma que, no Brasil, raramente se observou um corpo administrativo de funcionários dedicado a interesses objetivos e não pessoais. Formaram-se, ao longo da nossa História, círculos fechados, que se dedicam ao interesse privado em vez de aos impessoais. Entre esses círculos, a família é o principal, responsável pela propagação de vínculos em que prevalecem os laços de sangue e de coração. Esses laços são os que caracterizam o "Homem Cordial". Com lhaneza no trato, hospitalidade e generosidade, mas que não significam boas maneiras e, sim, um fundo emotivo forte e transbordante. Procura o brasileiro, com esse comportamento, fugir das formalidades da vida social e libertar-se do pavor de sentir-se isolado consigo mesmo.

Relações Cordiais são características dos brasileiros. Apresentam-se nas dificuldades de manter uma relação impessoal com seus superiores ou na linguística com a expressão diminutiva "-inho", que confere caráter pessoal ao tratamento entre pessoas; maneira de tornálas mais acessíveis e próximas do coração. Omite-se também o nome da família, pois se faz referência ao primeiro nome ${ }^{10}$. Manifesta-se relação de cordialidade também na religião, na

\footnotetext{
${ }^{10}$ Segundo Holanda (1995) a pessoalidade, demonstrada por essa forma de tratamento, é característica que remete aos portugueses, que só passam a utilizar o nome de família como forma predominante no tratamento a partir do século XII.
} 
qual os Santos são muito próximos dos devotos, em uma intimidade que, por vezes, torna-se desrespeitosa ${ }^{11}$. "Deus é um amigo familiar, doméstico e próximo - o oposto do Deus palaciano, a quem o cavaleiro, de joelhos, vai prestar sua homenagem, como a um senhor feudal" (HOLANDA, 1995, p. 149).

No próprio conceito de Homem Cordial estaria, portanto, a explicação para o nepotismo no Brasil. Sua origem está em traços de comportamento característicos dos nossos colonizadores, que se transferem do setor privado ao público. Se o nepotismo persiste é porque as relações familiares, típicas de um Estado patrimonialista não foram completamente superadas mesmo no Brasil contemporâneo. A obra "Raízes do Brasil", publicada originalmente em 1936, mostra claramente como as ideias de Holanda (1995) permanecem validas para explicar o funcionamento de nossa sociedade.

\section{O institucionalismo e sua consistência na explicação do nepotismo}

A teoria institucionalista possui uma diversidade de enfoques metodológicos ${ }^{12}$. Atualmente, os estudos dessa abordagem teórica têm procurado analisar o papel que as instituições exercem sobre o desempenho econômico. Nesse aspecto, têm feito grandes avanços principalmente ao observar como as instituições estimulam o avanço tecnológico e modificam as condições de produção nas diferentes nações. O estudo de Dias (2011), por exemplo, apresenta uma significativa revisão teórica, demonstrando que as instituições, juntamente com o capital físico e humano, determinam o desenvolvimento de longo prazo dos países. Utilizando a análise de Raymondo Faoro, o autor demonstra que o estamento burocrático se tornou ele mesmo uma instituição, consolidando uma forma de administração pública incapaz de criar instituições econômicas, políticas e sociais estáveis e eficientes na melhoria dos fatores de produção (educação e trabalho) e, por consequência, promotoras do crescimento. Outra importante constatação é que o estamento se tornou uma instituição com poderes de fato sobre os ganhos econômicos, o que entra em conflito com os poderes de júri, levando a instabilidade institucional e prejuízo na acumulação do capital. Enfim, o estamento levou ao controle dos poderes, dos processos distributivos (em favor próprio) e da formação do capital humano. $\mathrm{O}$ resultado é que "[...] o domínio das instituições de baixa qualidade sobre a dos insumos produtivos na História da Economia parece prevalecer ainda no Brasil” (DIAS, 2011, p. 20).

\footnotetext{
${ }^{11}$ A ausência de ritualismo nas celebrações religiosas é hábito presente nos brasileiros. Parece-nos estranho qualquer tipo de devoção formal, mais comum é um tipo de cordialidade que procura aproximar-nos das figuras religiosas, como se elas fossem parte de nossas relações familiares.

12 Ver texto de Conceição (2002).
} 
Embora o papel das instituições seja indiscutível no crescimento e que a consolidação do estamento no estado brasileiro seja importante para explicar a trajetória do País ao longo dos anos, tratamos essa instituição como geradora de outra instituição: o nepotismo, foco deste estudo. Embora a forma de gestão do estado e o próprio nepotismo possam trazer prejuízos ao crescimento, esse item está mais preocupado encontrar subsídios para explicar a persistência do nepotismo no Brasil a partir dos conceitos presentes no "antigo" e "novo" institucionalismo.

Especificamente, admite-se que o mal se enraizou em nossa sociedade como uma instituição informal de difícil eliminação. Assim, tanto o antigo institucionalismo como o novo nos fornecem os elementos necessários para explicar o problema. Ou seja, apesar de serem conceitos importantes na explicação do crescimento também são consistentes na explicação da inércia de qualquer instituição.

\subsection{O "antigo" Institucionalismo}

O que hoje é mais conhecido com "antigo" institucionalismo refere-se à concepção original de instituições que penetrou no campo de estudo econômico na década de 1920, surgindo como uma forte contraposição à corrente teórica neoclássica. Seu principal expoente é Thorstein Veblen, juntamente com Commons e Mitchel. A concepção de Veblen corresponde a uma visão evolucionária, muito diferente das análises neoclássicas que enfocam aspectos de equilíbrio do sistema. Pelo contrário, mudança e inovação são constantes nas ideias do autor e, por isso mesmo, são extremamente importantes no pensamento econômico atual.

O prefácio da "Teoria da Classe Ociosa" de Veblen traz o pensamento de Jacob Oser que sintetiza o que seria a essência do pensamento institucionalista. Para eles, a Economia deveria ser analisada como uma totalidade e não somente como a soma das partes. Dessa forma se enfatizava a importância das instituições ${ }^{13}$ na atividade econômica. Sua concepção teórica inspirava-se em Darwin e nas teorias evolucionistas, destacando que o fundamental era captar o movimento e a evolução das instituições econômicas em vez de acreditar em uma tendência ao equilíbrio. Sua crença era na existência de mudanças cumulativas e em desajustes na vida econômica. Longe de pensar em uma ordem harmônica que regula o funcionamento do mercado, acreditavam na existência de profundos choques de interesses na sociedade, cabendo

\footnotetext{
${ }^{13}$ Por instituições entendiam qualquer padrão organizado de comportamento coletivo, construtivo do universo cultural. Não se trata, portanto, apenas de instituições criadas com fins específicos (como escolas, prisões, bandos etc.) mas, todo um conjunto de usos e costumes, leis, códigos de conduta, modos de pensar e de agir culturalmente sacramentados. Para Veblen, instituições são "[...] hábitos estabelecidos de pensamento comum à generalidade dos homens"
} 
ao Estado regular os conflitos com políticas que visassem ao bem comum e ao melhor funcionamento do sistema econômico. Estavam também preocupados com a distribuição de renda, acreditando na necessidade de intervenção estatal para a adequada alocação de recursos e sua distribuição equânime.

Veblen, Common e Mitchel, ao centrarem sua análise nas instituições, desenvolveram uma linha analítica mais descritiva, deixando para segundo plano questões teóricas não resolvidas ${ }^{14}$. Ao citar Myrdal, Conceição (2001) mostra que o antigo institucionalismo ao se diferenciar da abordagem neoclássica ${ }^{15}$, consolida-se efetivamente como uma corrente teórica evolucionária. Entre as críticas dos “antigos” institucionalistas à Economia neoclássica, merece destaque a que considera a concepção de natureza humana. Para os neoclássicos, os indivíduos são vistos em termos hedonísticos, o que elimina o papel das instituições em sua análise. Um equívoco fortemente criticado por Veblen, pois segundo Monastério (2005), as instituições influenciam significativamente o comportamento dos indivíduos, seja impondo normas sociais que restringem sua conduta, seja agindo sobre os desejos dos agentes. Não há como considerar as pessoas isoladamente, como agentes socialmente passivos, inertes e imutáveis. É necessária uma visão evolucionária pela qual os instintos, hábitos e instituições exercem papel fundamental na evolução econômica.

Em Veblen, já se observam consistentes explicações para o fato de algumas instituições permanecerem enquanto outras evoluem e até mesmo desaparecem. Para ele, a evolução da estrutura social tem sido um processo de seleção das instituições, o que remete à ideia darwinista de seleção das espécies (Veblen apud Hodgson, 1993). Cabe destacar que tal processo de seleção não implica que as instituições sejam imutáveis, mas, sim, que pode haver mudança, seja ela radical ou incremental, pois mesmo que as instituições possam existir por longos períodos, estão sujeitas mundanças que resultam da alteração dos hábitos mentais (CONCEIÇÃO, 2001, p. 91). É um processo histórico e evolucionário, pois Veblen reconhece como o passado influencia no furuto através de um processo seletivo que age sobre os hábitos mentais fortalecendo ou alterando um ponto de vista que se formou no passado ${ }^{16}$ (VEBLEN apud CONCEIÇÃO, 2001, p.89).

\footnotetext{
14 Ver Conceição (2001)

${ }^{15}$ São três os pontos citados por Myrdal (apud Conceição, 2001) que diferenciam o institucionalismo da economia neoclássica: $1^{\circ}$ ) inadequação da teoria neoclássica em tratar as inovações, desconsiderando as condições de sua implantação e tratando-as como dadas; $2^{\circ}$ ) preocupação em como se dá a mudança e o crescimento em vez do equilíbrio estável; $3^{\circ}$ ) ênfase no processo de evolução e crescimento econômicos. Uma síntese da crítica de Veblen a teoria neoclássica pode ser encontrada Hunt e Sherman (1981).

${ }^{16}$ Embora Veblen considere as instituições como unidades de seleção evolucionária no sentido darwinista, sendo sua evolução resultado de uma seleção natural, ao longo de sua obra também se apresenta bem próximo da
} 


\subsection{Os Novos Institucionalistas: Coase, Williamson e North}

Os novos institucionalistas procuram analisar instituições e o crescimento econômico a partir de um enfoque microeconômico, com ênfase na teoria da firma, mas utilizando-se de uma abordagem não convencional, mesclada com História econômica, Economia dos direitos de propriedade, Sistemas Comparativos, Economia do Trabalho e Organização Industrial. Os principais expoentes dessa nova corrente teórica são Coase e Williamson (CONCEIÇÃO, 2001). Admite-se, contudo, que os estudos de Douglas North mereçam ser destacados, principalmente em função de sua abordagem fortemente histórica.

O trabalho clássico de Coase em 1937 preocupa-se em explicar existência da firma. A questão que surge é se o mercado é perfeito e faz tudo, por que existem as firmas ou qual a razão de existência de um empreendedor se os movimentos de preços é que regulam a produção? Em síntese: por que existem empresas? A resposta é que as organizações existem porque existem custos na utilização do mercado, existem custos de transação e a empresa tem como função a redução desses custos. Para o autor, os custos de transação existem porque, na utilização do mercado, existe informação imperfeita e os indivíduos não gozam de racionalidade ilimitada, sendo os custos de transação altamente influenciados por esses aspectos. Os custos de transação, assim como os incentivos à produção e à produtividade seriam determinadas pelo ambiente institucional, de forma que, juntos, influenciam no desenvolvimento econômico. Nesse sentido se coloca a afirmação de Coase (1991, p.01), ao receber o prêmio Nobel de Economia: "It makes little sense for economists to discuss the process of exchange without specifying the institutional setting within which the trading takes place, since this affects the incentives to produce and the costs of transacting".

Mais que visões divergentes, os trabalhos de Coase e Williamson são complementares e aprofundam o estudo dos Custos de Transação, inclusive existe dificuldade em apontar o verdadeiro fundador dessa linha de pesquisa. Se observarmos o trabalho de Williamson (1999) denominado "The Economics of Transaction Costs", constatamos diversas referências a Coase. Contudo, Williamson aborda com maior profundidade, os aspectos internos de organização da firma. Essa é uma de suas grandes contribuições, pois, ao enfocar a racionalidade limitada e o oportunismo, a complexidade, a incerteza e a especificidade dos ativos, mostra como se altera

\footnotetext{
hipótese da herança das características adquiridas. Esse tipo de pensamento aproxima-o do "lamarckismo", assumindo que as mudanças ocorridas nas instituições são preservadas ao longo do tempo, através de processos cognitivos e da inércia dos hábitos de pensamento (MONASTÉRIO, 1998)
} 
a organização das empresas. Portanto, as transações se tornam fundamentais, pois, além de determinarem a organização das firmas, influenciam na sua estrutura hierárquica ${ }^{17}$.

Interessa-nos mais, no entanto, a analise de Williamson (2000) sobre a mudança institucional. Para o autor, a Nova Economia Institucional pode ser divida em diferentes níveis de análise de acordo com sua frequência de mudança e seu propósito. O quadro 1 resume tal classificação, que nos serve perfeitamente para análise do tema em estudo.

Quadro 1: Classificação das Instituições de acordo com a frequência e o propósito

\begin{tabular}{|l|l|l|}
\hline NÍVEL & FREQUÊNCIA DE MUDANÇA & \multicolumn{1}{|c|}{ PROPÓSITO } \\
\hline $\begin{array}{l}\text { Embeddeness } \\
\text { (Instituições Informais) }\end{array}$ & 100 a 1000 anos & Afirmação do Status Quo \\
\hline $\begin{array}{l}\text { Ambiente Institucional } \\
\text { (Instituições Formais) }\end{array}$ & 10 a 100 anos & Reduzir a incerteza \\
\hline Governança & 1 a 10 anos & Reduzir Custos de Transação \\
\hline Alocação de Recursos & Instantânea & Eficiência \\
\hline
\end{tabular}

Fonte: adaptado de Williamson (2000)

Observe-se que para Williamson (2000), as instituições informais ou as que se encontram no nível "embeddness" são as mais difíceis de serem alteradas, especialmente porque seu propósito é a afirmação do status dos indivíduos. Por outro lado, no nível de alocação de recursos, temos uma rápida alteração institucional, porque ela tem o objetivo de aumentar a eficiência produtiva. No nível intermediário, encontram-se as instituições formais que levam de 10 a 100 anos para alterarem-se e objetivam reduzir a incerteza - e a governança, que leva de 1 a 10 anos para mudar e objetiva reduzir os custos de transação.

A mudança institucional é foco de estudo também de Douglas North. Ganhador do prêmio Nobel em 1993, North mostra preocupação em analisar a evolução das instituições, porque acredita que elas sejam determinantes do desempenho econômico. Nesse caso, ao avaliar a evolução institucional, North (1993) afirma que a História é importante, porque nos fornece um marco analítico capaz de proporcionar o entendimento da mudança econômica ${ }^{18}$. Para o autor, as instituições são criação humana que delimitam a estrutura social, política e

\footnotetext{
${ }^{17}$ Nesse caso, a teoria da firma sofre grande avanço porque a partir dessas abordagens é possível a fusão entre a estrutura organizacional interna da firma e a estrutura de mercado (inclusive instituições), explicando-se a conduta e o desempenho de determinadas indústrias, assim como as demais estruturas presentes.

${ }^{18}$ Nesse aspecto, o discurso de North (1993) critica a teoria neoclássica em dois pontos: i) que as instituições não têm importância, e ii) que o tempo não importa.
} 
econômica. As instituições são definidas por limites informais ${ }^{19}$ (sanções, tabus, costumes, tradição, códigos de conduta etc.) e regras formais (constituições, leis, direitos de propriedade, etc.). Servem para criar a ordem, reduzir a incerteza, definir as escolhas e são, ainda, as determinantes dos custos de produção e transação e, por consequência, da viabilidade e lucratividade da atividade econômica.

As instituições são as responsáveis por conectar o passado com o presente e o futuro, podendo explicar as mudanças econômicas nas nações (crescimento, estagnação e declínio). Nesse caso, o autor discute profundamente a estabilidade e a mudança institucional, ou seja, por que algumas instituições permanecem enquanto outras se modificam. As conclusões são de que a estabilidade é composta por um conjunto complexo de coações que incluem regras formais e informais. Já a mudança institucional é um processo incremental (embora também possa ser resultado de uma revolução) influenciado pelas mudanças que ocorrem nos preços relativos da sociedade e pelas variações nos gostos ou nas preferências. Isso, portanto, levaria a uma mudança nas regras da Economia (estruturas formais) e nos costumes (estruturas informais).

Ao se deter na mudança institucional, North (1995) apresenta a razão de permanência de instituições ineficientes ao longo do tempo. A explicação vem por meio de uma análise de caráter histórico. Com isso, pode-se explicar a existência de trajetórias dependentes ${ }^{20}$ (Path Dependence). Mais ainda, depois de determinado um curso (trajetória) existem incentivos (externalidades ou aprendizado) que tendem a manter esse curso. Também se formam grupos de interesse, com retornos crescentes, que tendem a impedir uma mudança institucional (moldarão as instituições segundo os seus desejos). Assim, surgem estruturas que garantem oportunidades para instituições produtivas e improdutivas e gera-se uma trajetória dependente difícil de ser revertida. Algumas vezes existe uma tendência à estabilidade nos modelos de troca (trajetória-dependente), enquanto em outros existe uma tendência à mudança dinâmica. As razões que determinam tais condições são a expansão dos mercados e a divisão do trabalho. Portanto, em algumas sociedades pouco desenvolvidas, existem formas de troca com aparato institucional simples e estável historicamente, enquanto, em sociedades mais desenvolvidas, os mercados são mais complexos e determinam a necessidade de uma constante mudança do aparato institucional.

\footnotetext{
${ }^{19}$ Para North (1993), embora as regras formais possam ser alteradas do dia para noite, as normas informais só podem alterar-se de modo gradual. Assim, são as normas informais que dão suporte as regras formais.

${ }^{20} \mathrm{O}$ autor salienta, então, o papel fundamental das escolhas econômicas e políticas na determinação da trajetória de crescimento a ser adotada.
} 


\section{De Portugal ao Brasil: como as instituições portuguesas se estabelecem em nossa sociedade}

Se nos detivermos na análise de algumas instituições que herdamos de nossos colonizadores, observaremos que a prática do nepotismo é uma delas, conforme já foi constatado nas interpretações de Faoro (2001) e de Holanda (1995). O nepotismo, contudo, está ligado ao que Noguerol (2008) considera outra instituição transmitida pelos portugueses: o personalismo. Para o autor, a sociedade que se estabeleceu na América Portuguesa era extremamente personalista ${ }^{21}$ e esses tipos de relações eram fundamentais para sobrevivência das famílias e indivíduos que se aproximavam do Estado para garantir oportunidades de ganhos.

O personalismo que se firma no Estado brasileiro é traço característico do Estado português. Veja-se sobre isso a análise de Fragoso et al. (2001), que demonstra o peso do Estado português na regulação da vida social, com expressiva representação do funcionalismo civil e militar $^{22}$ e enorme representatividade da elite política. Conforme Monteiro (1998 apud Fragoso et al., 2001) uma das consequências de tal fenômeno foi o fato de que, entre 1750 e 1792, 30 das 52 casas da alta nobreza do Brasil ${ }^{23}$ tinham mais de $50 \%$ dos seus rendimentos retirados dos bens concedidos pela coroa. Apesar da aceitação de que esses privilégios são uma herança da nossa colonização, resta questionar: como especificamente as instituições portuguesas (inclusive os privilégios e o nepotismo) se estabeleceram no País? Quais foram os agentes responsáveis por essa transmigração?

Evidentemente, o Brasil, ao se tornar independente, seria representado por uma elite política ideologicamente homogênea, devido à formação jurídica em Portugal e que herdaria um pensamento semelhante ao da elite portuguesa que dirigia o Estado ${ }^{24}$. Respostas mais precisas, contudo, são apresentadas em Fragoso et al. (2001). Para o autor, a partir de 1415, com a tomada de Ceuta, as práticas do Estado português foram definitivamente transmitidas ao

\footnotetext{
${ }^{21}$ Nogueról (2008) analisa o personalismo e algumas outras instituições que normalmente se relacionam como pertencentes a América Portuguesa. São elas: Os latifúndios, a escravidão, o colonialismo e o absolutismo, e os privilégios e monopólios.

22 Deve-se ressaltar sobre isso que, segundo Fragoso et al. (2001), em 1607, só o gasto com pensões oferecidas aos serviços prestados representava 190 contos. Um volume muito elevado se se considerar que a arrecadação do Estado no Império Atlântico representava 167 contos.

${ }^{23}$ No Brasil houve, de direito, pouquíssimas famílias nobres no período colonial. No entanto, o fato não impediu que os costumes criassem uma "nobreza da terra". Isto é, famílias que se estabeleceram em diferentes pontos da colônia e que ou pela força ou pela riqueza e, comumente pelas duas coisas, dominaram as diferentes capitanias utilizando-se do Estado para manter o poder e auferir mais riqueza.

${ }^{24}$ Ver Carvalho (1980)
} 
ultramar. O Governo, à medida que aumentava suas conquistas, tendia a distribuir postos administrativos ou militares (ex: governador, provedor da fazenda etc.) de forma deliberada." 25

Ao procurar desvendar a origem do capital primitivo na colônia brasileira, Fragoso et al. (2001) fazem um estudo das primeiras famílias que se estabeleceram no Rio de Janeiro nos séculos XVI e XVII. Essas famílias, que se tornariam posteriormente os donos de engenhos ou famílias tradicionais do País, na condição de conquistadores ou de primeiros povoadores ${ }^{26}$ passaram também a compor a administração pública, ou seja, estavam no comando da formação da sociedade colonial no recôncavo do Guanabara.

A questão fica ainda mais evidente quando observamos que do total de 197 famílias senhoriais conhecidas no século XVII, 89 (45\%) tiveram origem em um oficial ou ministro do Rei. Dessas 89 famílias, 73 foram constituídas entre 1566 e 1720, pertencendo aos conquistadores ou primeiros povoadores. Mais ainda, entre as famílias que mantiveram seu status e engenhos por mais de três gerações, 2/3 descendiam dos conquistadores, primeiros povoadores ou de oficiais do rei. Essas foram as famílias que, ao longo do século XVII, dominaram os assentos da câmara e formaram a elite política da colônia. Assim sendo, “[...] as melhores famílias da terra eram produtos das práticas e instituições - e de suas possibilidades econômicas - do Antigo regime português [...]" (FRAGOSO et al., p. 42).

Uma prática muito antiga é, portanto, a política de favorecimento a amigos e a parentes de quem ocupa cargo público. As práticas do Estado português apresentadas anteriormente sem dúvida se transmitiram ao nosso País. No Rio de Janeiro, as primeiras famílias a se estabelecerem trouxeram consigo uma instituição muito comum em Portugal. Quaisquer postos públicos eram desejados não apenas pelos salários pagos, mas, principalmente, pelos demais ganhos que se poderiam deles retirar. O cargo era mais utilizado em benefício próprio do que a

\footnotetext{
${ }^{25}$ Além dos vencimentos, tais postos eram desejados, porque poderiam oferecer privilégios mercantis, tais como exclusividade em viagens marítimas, isenção de taxas e direitos alfandegários. O sistema de benesses, típico no Estado português e ampliado com suas conquistas, possibilitava ainda "[...] o uso dos postos concedidos pela coroa, para fins menos nobres do que servir ao rei” (FRAGOSO et al., 2001, p. 45). Diferentemente do que ocorreu na Inglaterra, onde o exercício da atividade pública não se vinculava a preocupações materiais, em Portugal representava o sustento dos antigos nobres. Um sistema de mercês se originou nas guerras de reconquista contra os muçulmanos em Portugal na Idade Média. Como recompensas à aristocracia portuguesa pelos serviços prestados à coroa na época de guerra foram oferecidos terras e privilégios. Esse tipo de sistema reforçava o caráter corporativo da monarquia portuguesa, que se baseava no benefício (HESPANHA, 1993 apud FRAGOSO et al., 2001).

${ }^{26}$ As primeiras 14 famílias e seus descendentes que desembarcaram no Rio de Janeiro entre 1565 e 1600 e que se tornariam senhoriais, Fragoso et al. (2001) chama de conquistadores, a segunda onda migratória, cerca de treze famílias que chegaram entre 1601 e 1620 são chamadas pelo autor de primeiros povoadores. As famílias que se originaram do matrimônio entre as descendentes dos conquistadores e primeiros povoadores com forasteiros e que mais tarde constituiriam moendas são denominadas de famílias extensas ou linhagens. Por fim, as que não absorveram genros estrangeiros e que deram origem a outras casas senhoriais são denominadas como famílias simples.
} 
serviço da coroa. Um excesso de intervencionismo nas atividades de mercado se consolida. Algumas pessoas, eleitas pelo rei, recebiam o monopólio de exploração de alguns serviços e esses serviços, embora não fossem exclusivos de algumas poucas famílias, normalmente eram repassados de pai para filho. Sob o nome de "Economia do bem comum" garantia-se que uma série atividades comerciais fossem exercidas com exclusividade por alguns, que enriqueciam à custa da sociedade (FRAGOSO et al., 2001)

A resposta de João Rodrigues de Britto ao inquérito feito por Sua Alteza Real, D. Maria, Rainha de Portugal, a respeito dos fatores que impediam a prosperidade da Bahia, descreve as dificuldades que o comércio vivenciava frente ao excesso de intervencionismo Real. Nas palavras de Britto, em 1807, observamos o fato: "Se lançarmos os olhos sobre os outros distritos da capitania, o quadro não será menos triste; por toda a parte não se vê senão monopólios, subsídios, taxas e impostos de toda a casta, estabelecidos sem legítima autoridade, nem reconhecimento da S.A.R” (BRITTO, s/d, p. 81). Favores, estímulos e privilégios sempre estiveram presentes em nossa História. Sem dúvida não foram inventadas, mas sim vieram junto com diversas instituições, que se procurou implantar no país.

\section{As tentativas de eliminação do nepotismo: a persistência do problema a partir do excessivo número de cargos de confiança existentes no Brasil}

Apesar de a polêmica sobre o nepotismo ser mais significativa atualmente, as tentativas de eliminar essa prática vêm de longa data. Essas tentativas são apresentadas na forma de lei, mesmo surtindo pouco efeito prático. A Constituição de 1934 já proibia o ingresso na carreira pública sem que o candidato fosse previamente aprovado em concurso. No artigo 170, que delibera sobre o funcionalismo público, afirmava o seguinte:

Art 170 - O Poder Legislativo votará o Estatuto dos Funcionários Públicos, obedecendo às seguintes normas, desde já em vigor:

(...)

$\left.2^{\circ}\right)$ a primeira investidura nos postos de carreira das repartições administrativas, e nos demais que a lei determinar, efetuar-se-á depois de exame de sanidade e concurso de provas ou títulos (Art. 170 da C.F. de 1934)

Apesar da clara determinação constitucional, a lei evidentemente não foi cumprida. As constituições de 1937 e de 1946 repetiram a redação anterior. A Constituição de 1969 mostra novamente o requisito de concurso público para ingresso no funcionalismo do Estado, dessa vez no seu artigo 97. Em 1988, a nova Constituição, nos anseios por uma sociedade democrática e com livre oportunidade para todos afirmava o seguinte: 
Art. 37. A administração pública direta, indireta ou fundacional, de qualquer dos Poderes da União, dos Estados, do Distrito Federal e dos Municípios obedecerá aos princípios de legalidade, impessoalidade, moralidade, publicidade e, também, ao seguinte:

I - os cargos, empregos e funções públicas são acessíveis aos brasileiros que preencham os requisitos estabelecidos em lei;

II - a investidura em cargo ou emprego público depende de aprovação prévia em concurso público de provas ou de provas e títulos, ressalvadas as nomeações para cargo em comissão declarado em lei de livre nomeação e exoneração (C.F. de 1988)

A Constituição, mais uma vez, procura proibir a ocupação de cargos que não por meio de concurso. No entanto, o inciso II apresenta uma ressalva, pois afirma a possibilidade de nomeação de funcionários para cargos comissionados. Uma análise e interpretação mais minuciosas da lei não é objetivo do trabalho, contudo, atualmente, o debate é exatamente quanto ao número exagerado de cargos de confiança existentes no Brasil, o que abre possibilidade para ocorrência de nepotismo ou nepotismo cruzado $^{27}$. Conforme Figura 1, em vez de se estarem reduzindo frente à condenação constitucional e atenção atual dos meios de comunicação, o crescimento no número de cargos de confiança tem sido significativo.

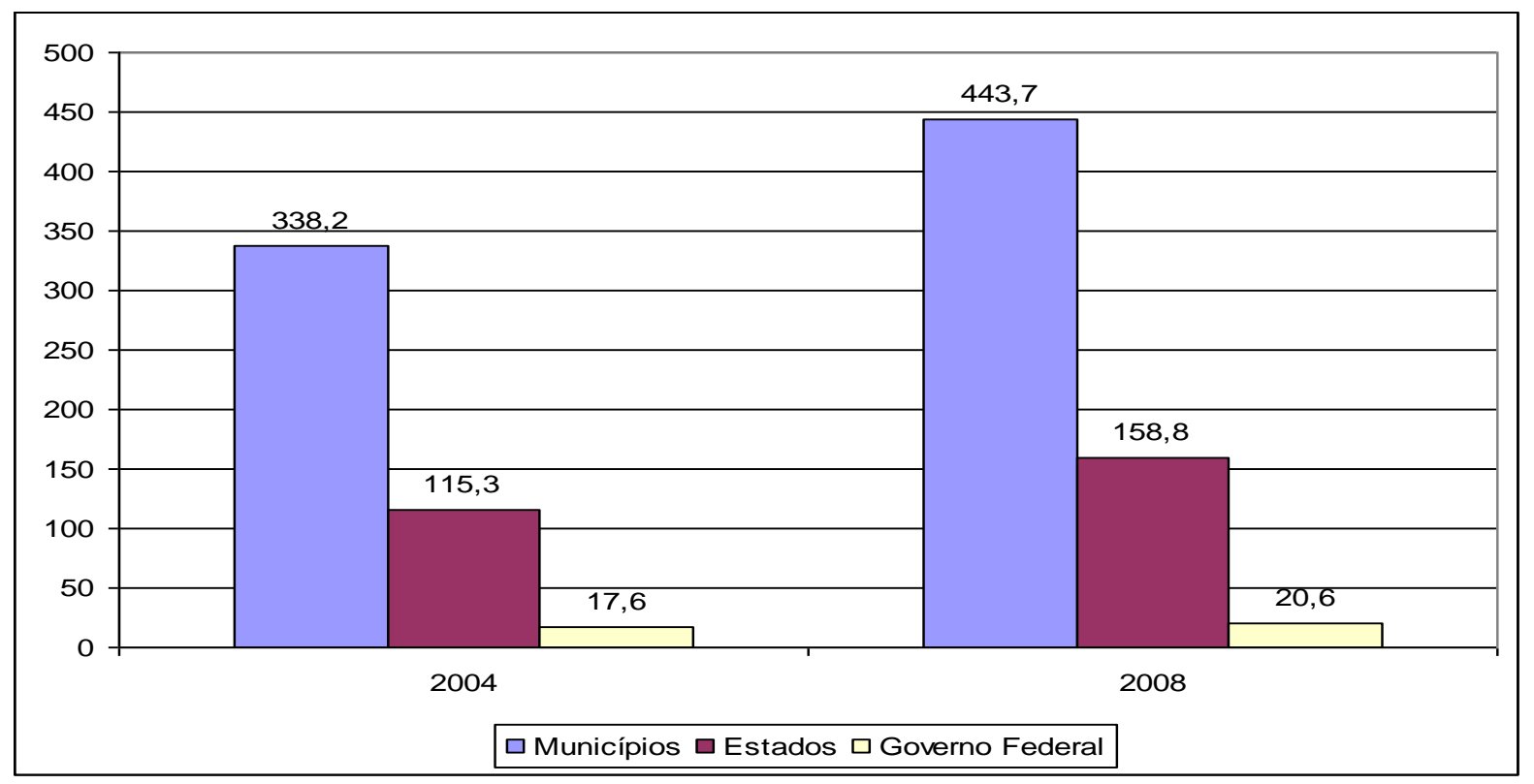

Figura 1: Crescimento do número de cargos de confiança de 2004 para 2008 (em mil) Fonte: IBGE, Ministério do Planejamento e secretarias estaduais de administração (apud Folha de São Paulo)

\footnotetext{
${ }^{27}$ Nepotismo cruzado pode ser definido como a troca de cargos entre parentes de agentes públicos para que eles sejam contratados sem concurso. Ou seja, ocorre quando um gestor público emprega parente de outro e como troca algum parente seu é empregado pelo primeiro.
} 
Os dados mostram que o problema persiste nas três esferas de Governo. Nos cinco anos considerados o número total de cargos de confiança aumentou de 470.000, no início de 2004 para um total de 621.000 em 2008, o que corresponde a um aumento médio de $32 \%$. A participação dos comissionados em relação ao total de funcionários no ano de 2008, corresponde a 8,8\% nos municípios, 6,0\% nos Estados e 3,8 no Governo Federal.

Se observarmos o crescimento nos cargos de confiança comparativamente ao número ao total do funcionalismo, observamos grande discrepância (ver Figura 2). De 2004 para 2008, o número de cargos de confiança aumentou 31,2\% nos municípios, 36,85\% nos Estados e 17,3\% na União, contra um crescimento no total do funcionalismo de 17,1 nos municípios, 12,23\% nos Estados e 7,67\% na União.

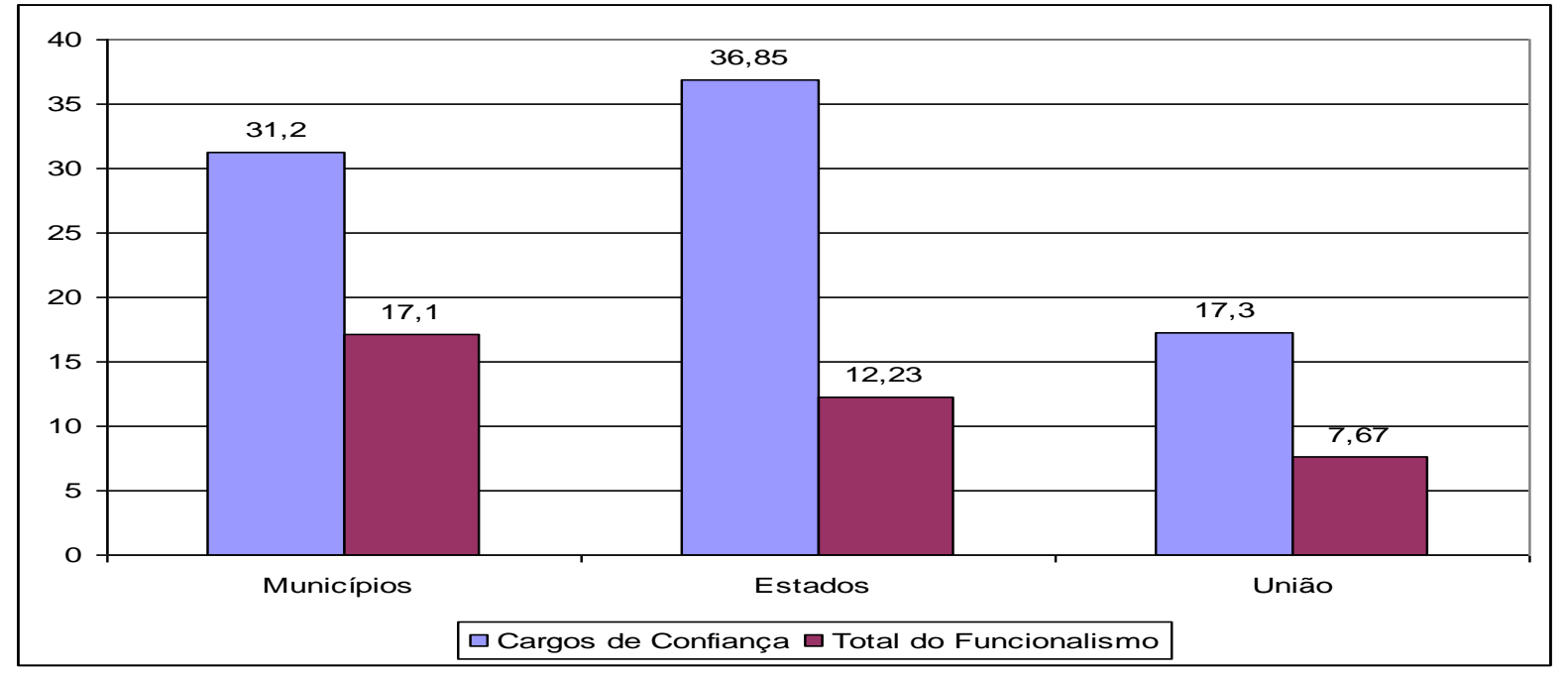

Figura 2: Crescimento nos cargos de confiança e no total do funcionalismo nas três esferas de Governo (2004-2008)

Fonte: Fonte: IBGE, Ministério do Planejamento e secretarias estaduais de administração (apud Folha de São Paulo)

Se considerarmos os poderes Executivo e Legislativo federais, observamos que o número de comissionados em relação aos funcionários efetivos atinge 3,8\% no primeiro e o absurdo de $45 \%$ e $27 \%$ no Senado Federal e na Câmara dos Deputados (ver tabela 1). 
Tabela 1: Número de Cargos de Confiança no Brasil

\begin{tabular}{lcccc}
\hline & $\begin{array}{c}\mathrm{N}^{\circ} \text { de Funcionários } \\
\text { Efetivos }\end{array}$ & $\begin{array}{c}\mathrm{N}^{\mathbf{o}} \text { de Cargos } \\
\text { Comissionados }\end{array}$ & $\begin{array}{c}\text { Total (efetivos e } \\
\text { comissionados) }\end{array}$ & $\begin{array}{c}\text { Percentual dos } \\
\text { comissionados }\end{array}$ \\
\hline Governo Federal & 529.003 & 20.600 & 549.423 & 3,8 \\
\hline Senado & 3.461 & 2.785 & 6.246 & 45 \\
\hline Câmara Federal & 3.500 & 1.270 & 4.770 & 27 \\
\hline
\end{tabular}

Fonte: Governo Federal e Congresso Nacional (apud Gazeta do Povo)

Os números ficam ainda mais impressionantes quando se estabelece um quadro comparativo entre os cargos comissionados no Governo Federal do Brasil e em alguns países desenvolvidos. A Figura 3 ilustra a discrepância no número de cargos de confiança no Governo Federal, comparativamente a outras nações.

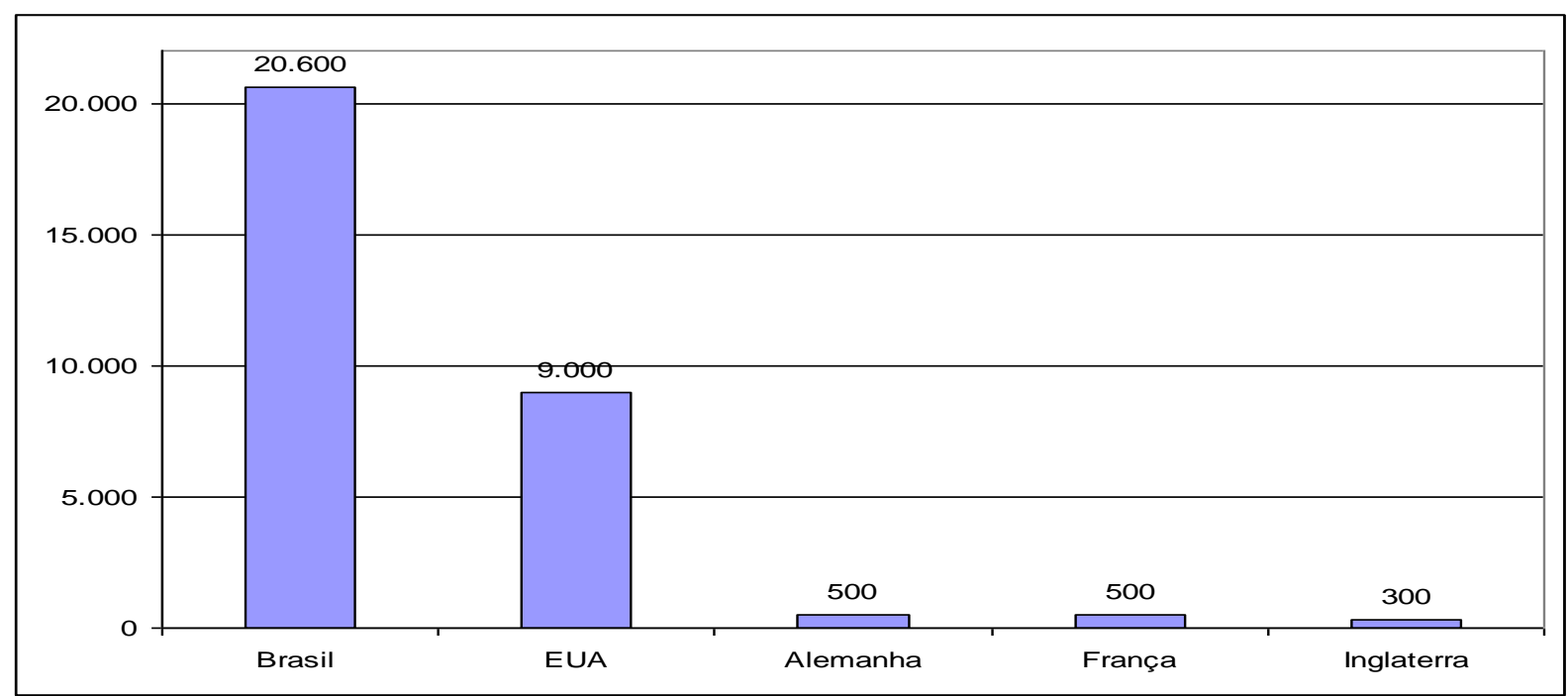

Figura 3: Número de cargos comissionados no Brasil e em alguns países desenvolvidos Fonte: Governo Federal e Congresso Nacional (apud Gazeta do Povo)

Enquanto, no Brasil, o número de cargos comissionados no Governo Federal ultrapassa os 20.000, nos E.U.A é de 9.000. São 500 na Alemanha e França e apenas 300 na Inglaterra. O que tenta a Constituição - mostrar que cargo público não pode ser ocupado pelo simples desejo do governante, principalmente quando se trata de oferecer cargos a parentes — parece não vingar no Brasil.

Não é por acaso que no dia no dia 21 de agosto de 2008 foi aprovada pelo Supremo Tribunal Federal (STF), a Súmula Vinculante $n^{\circ}$ 13, que proíbe o nepotismo nos três poderes — Executivo, Legislativo e Judiciário - e em todas as esferas de Governo: federal, estadual e municipal. A vinculante esclarece o Art. 37 da Constituição, proibindo: 
A nomeação de cônjuge, companheiro ou parente em linha reta, colateral ou por afinidade, até o terceiro grau, inclusive, da autoridade nomeante ou de servidor da mesma pessoa jurídica, investido em cargo de direção, chefia ou assessoramento, para o exercício de cargo em comissão ou de confiança, ou, ainda, de função gratificada na Administração Pública direta e indireta, em qualquer dos Poderes da União, dos Estados, do Distrito Federal e dos municípios, compreendido o ajuste mediante designações recíprocas, viola a Constituição Federal (STF, Súmula Vinculante no 13).

O Ministério Público tem combatido a prática do nepotismo no Brasil há algum tempo. Essa luta é reforçada com a vinculante do STF aprovada nesse ano. No entanto, ainda é cedo para afirmar que o problema será solucionado, porque a prática é recorrente e tem-se perpetuado em nossa cultura. Em pesquisa divulgada pela Universidade de Brasília no ano de $2008^{28}$, feita a pedido da comissão de Ética Pública (órgão vinculado à Presidência da República), constatouse que a maioria dos cidadãos pesquisados tolera a prática do nepotismo. Mais especificamente, $50,3 \%$ dos pesquisados admitiram que, se pudessem, contratariam parentes. Entre os servidores públicos entrevistados, 32,1\% fizeram mesma afirmação. Isso ajuda a explicar por que os cargos de confiança crescem e não são condenados pela população e autoridades.

\section{A explicação do nepotismo: a convergência entre os conceitos de Estamento Burocrático, Homem Cordial e o Institucionalismo}

É possível encontrar uma explicação para persistência do nepotismo no Brasil tanto na análise histórica de Raymundo Faoro como na de Sérgio Buarque de Holanda. A explicação fica completa quando consideramos o nepotismo como uma instituição informal que se enraizou em nossa sociedade.

Considerando-se inicialmente as análises de Raymundo Faoro e de Sérgio Buarque de Holanda, observamos que os autores convergem na explicação de que muitos dos problemas observados atualmente no Brasil têm raízes históricas, em especial provindas da nossa colonização. Na análise de Faoro, o nepotismo seria explicado pela persistência de um Estado de características patrimonialistas que daria origem ao Estamento burocrático, formado por pessoas que colocam seus interesses acima dos interesses da sociedade. Embora essa camada ou classe dirigente não esteja unida por laços familiares, utiliza o setor público em benefício próprio, de forma que não lhe é estranha a nomeação de parentes para o exercício de atividades

\footnotetext{
28 A pesquisa foi realizada pelo professor Ricardo Caldas da UnB. Foram ouvidas 1.167 pessoas de várias profissões em todo país e 1.027 servidores públicos de seis estados (SP, MG, PA, PB, PR e RJ) e Distrito Federal. Entre estes últimos, 8,5\% disseram ter obtido o cargo por meio da indicação de um parente, 16,2\% por meio de contatos políticos $12,1 \%$ por indicação de amigos e $44,3 \%$, por meio de concurso público.
} 
públicas. Holanda (1994), por sua vez, também mostra que a dificuldade de separação entre o público e o privado é uma das características da nossa sociedade. Assim como Faoro (2001), acredita que na consolidação do Estado patrimonialista esteja a origem do problema. Esse Estado inibe a formação do Estado burocrático e estabelece relações de poder que ao invés estarem calcadas no mérito pessoal enfatizam as relações pessoais. Trata-se de um Estado que barra o desenvolvimento econômico, por estar mais interessado em orientar as ações dos indivíduos para auferir ganhos do que deixar florescer a livre iniciativa e a racionalidade econômica. Além de mencionar o patrimonialismo, Holanda (1994) enfoca os problemas de uma sociedade patriarcal. A explicação do nepotismo viria, então, em função do predomínio das relações familiares, presente na sociedade escravista brasileira e que se mantém vivas até nossos dias.

Herança da colonização Portuguesa, a repulsa às virtudes econômicas é apresentada pelos dois autores de forma incisiva. O maior prestígio social seria decorrência não das atividades laboriosas, mas, sim, daquelas que não necessitassem de grande esforço físico ou trabalho manual. Em um Estado do tipo patrimonialista, que avaliza esse tipo de conduta, o cargo público se torna a melhor opção de emprego, pois a tradição garante o prestígio e poder de um nobre, com ganhos econômicos significativos, além, é claro, da possibilidade de longa permanência no cargo e de benesses para familiares ou pessoas próximas.

Enquanto a interpretação de Faoro (2001) evolui no conceito de Estamento Burocrático, a análise de Holanda (1994) conclui-se no "Homem Cordial". São as relações de sangue e coração que se estabelecem na sociedade brasileira. Quando as relações pessoais se sobrepõem às impessoais, especialmente no Estado, gera-se uma série de problemas na administração pública que barram o desenvolvimento econômico. O desenvolvimento de um Estado burocrático, com funcionários eficientes e capazes de promover o desenvolvimento capitalista pára na concessão de favores e privilégios a determinados grupos sociais. Quando relações desse tipo estão presentes, o problema do nepotismo fica facilmente explicável. A gestão pública passa a obedecer à vontade dos governantes que, além de se perpetuarem em cargos, empregam seus parentes, como se o Estado fosse uma típica extensão familiar.

O "Homem cordial" de Holanda (1995) não vê problemas em oferecer cargos públicos a seus parentes, afinal é o coração que guia suas ações. Da mesma forma, os pertencentes ao Estamento governam em benefício próprio, propagam-se no Poder como se o Estado fosse sua propriedade. Se unirmos as interpretações de Faoro (2001) e de Holanda (1995) com a corrente instituicionalista, teremos explicada a razão de persistência do problema. Se analisamos a 
questão sob o enfoque do "antigo" institucionalismo, especialmente de Veblen, temos uma abordagem evolucionária das instituições, o que nos explica a mudança sob uma ótica darwinista. Por outro lado, assim como nos mostra como a mudança institucional ocorre, Veblen também explicita que ela pode não se realizar. Em uma análise de caráter histórico, o autor afirma que a situação de hoje define as instituições de amanhã, mas lembra: alterando ou fortalecendo um ponto de vista ou uma atitude mental trazida do passado até aqui.

O novo institucionalismo, apesar de focalizar o mercado e os custos de transação, tornase útil para explicar o nepotismo na medida em que também explica a razão de persistência de algumas instituições. Instituições evoluem juntamente com a complexidade dos mercados, que tornam significativos os custos de transação. Se observarmos especificamente a análise de Williamson (2000) veremos que as instituições informais são as que mais tempo levam para se alterarem. Estão no nível "Embeddness" e lembre-se: sua função é garantir o status quo dos indivíduos. Na abordagem de Douglas North, temos o conceito de Path Dependence, ou seja, depois de escolhida uma trajetória existem incentivos (externalidades ou aprendizado) que tendem a manter esse curso, e mais, podem formar-se grupos de interesse contrários à mudança institucional, determinando estruturas que garantam oportunidades para instituições produtivas e improdutivas.

Unindo-se a interpretação de Faoro (2001) à de Holanda (1995), temos uma explicação plausível para o nepotismo brasileiro, além de serem interpretações relevantes na explicação de diversas outras mazelas observadas na sociedade atual. São convergentes, portanto, as interpretações dos autores, que, amparadas na visão institucionalista, explicam por que o nepotismo persiste desde nossa colonização. No Estamento e na Mentalidade Cordial estão a origem do Nepotismo, que persiste como uma norma informal, apesar de regras formais tentarem eliminar essa prática. Evidencia-se essa afirmação quando se observam os dados da pesquisa realizada pela $\mathrm{UnB}$, mostrando que grande parte dos brasileiros pesquisados toleram a prática do nepotismo e, se pudessem, contratariam parentes para o exercício de atividades públicas.

\section{Considerações finais}

Apesar das tentativas constitucionais de eliminação do nepotismo, observa-se que a prática continua presente em nossa sociedade. Dessa forma, este trabalho teve como objetivo analisar o nepotismo no Brasil de acordo com as interpretações históricas de Raymundo Faoro 
e de Sérgio Buarque de Holanda, utilizando um enfoque institucionalista para explicar a persistência problema.

Na interpretação de Faoro, foi possível explicar o nepotismo via conceito de Estamento Burocrático. Formou-se, em nossa sociedade, um grupo de indivíduos que monopolizam o poder e utilizam-se do Estado em beneficio próprio. Já na interpretação de Holanda (1995), o nepotismo pode ser explicado por sua definição do brasileiro como "Homem Cordial". São as relações de sangue e de coração que guiam as ações do nosso povo e a cordialidade faz com que os indivíduos coloquem as relações pessoais à frente das impessoais. Aliando-se tais análises com uma visão institucionalista, foi possível encontrar diversos elementos que convergem para a explicação do problema. Apesar de serem criadas instituições formais visando à eliminação da prática, o nepotismo enraizou-se como uma instituição informal e esta, conforme a corrente dos "antigos" e "novos" institucionalistas, é de mais difícil eliminação. Espera-se, contudo, que tais instituições evoluam e que não seja necessário um milênio para que sejam superadas.

Por fim, cabe destacar que um olhar sobre a História nos traz explicações para diversos problemas que acometem nossa sociedade. Passados diversos séculos da nossa colonização, muitas características presentes no Brasil-colônia ainda persistem e são característicos da nossa formação social. Romper com essas mazelas seria condição necessária não só para superar o nepotismo, mas também garantir nosso próprio desenvolvimento.

\section{Referências}

ABNT Associação Brasileira de Normas Técnicas. NBR 14.724, de 17.03.2011.Informação e documentação, trabalhos acadêmicos, apresentação. Válida a partir de 17.04.2011. Rio de Janeiro, 2011.

BRASIL. CONSTITUIÇÃO DA REPÚBLICA DO BRASIL (constituições de 1934, 1937, 1947, 1969 e 1988). Disponível em www. http://www.planalto.gov.br. Acesso em 23 de Dezembro de 2008.

BRITO, J.R. A resposta de João Rodrigues de Brito ao Ofício do Governador da Bahia em atenção as informações requeridas por Sua Alteza Real, o Príncipe Regente Senhor Dom João, In: Calmon, F.M. de G. A economia brasileira no alvorecer do século XIX - coleção de estudos brasileiros, Salvador, Livraria Progresso, s.d.

CAMINHA, P.V. Carta a El Rei D. Manuel. Dominus: São Paulo: 1963. Disponível em <www.cce.ufsc.br/ nupil/literatura/carta.html>. Acesso em 19 de fevereiro de 2009. 
CARVALHO, J.M. A construção da ordem: A elite política imperial. Rio de Janeiro: Campus, 1980.

COASE, R. The nature of the firm: origins, evolution, and development. New York; Oxford: Oxford University, 1993.

The Institutional Structure of Production. Discurso de Coase ao receber o Prêmio Nobel de Economia em 1991. The American Economic Review. Volume 82, Issue 4 Sept. 1992, 713-719.

CALDAS, R. 50\% dos brasileiros toleram nepotismo, aponta pesquisa. Folha de São Paulo. 5 de novembro de 2008. Disponível em <http://<www1.folha.uol.com.br/folha/brasil/ult96u464303.shtml >. Acesso 26 de fevereiro de 2009.

CONCEIÇÃO, O. A. C. Instituições, crescimento e mudança na ótica institucionalista. Porto Alegre: Fundação de Economia e Estatística Siegfried Emanuel Heuser (FEE), 2001.

A contribuição das abordagens institucionalistas para a Constituição de uma teoria econômica das instituições. Ensaios FEE, Porto Alegre, v. 23, n. 1, p. 77-106, 2002.

DIAS, J. Instituições, Crescimento e Desenvolvimento Econômico no Brasil: as teorias modernas e de Raymundo Faoro. IN: II Conferência do Desenvolvimento, Code II, IPEA, Brasília, 2011.

FOLHA DE SÃO PAULO. Cargos de confiança crescem $32 \%$ no país em cinco anos. Reportagem publicada em 15 de Janeiro de 2009.

FRAGOSO, J; BICALHO, M. F.; GOUVEA, M.F. O antigo regime dos trópicos: a dinâmica imperial portuguesa. Rio de Janeiro: Civilização Brasileira, 2001.

FREIRE, G. Casa Grande \& Senzala. 34. ed. Rio de janeiro: Record, 1998.

GAZETA DO POVO. Disponível em <www.rcp.com.br/gazetadopovo. Acesso em 05 de Janeiro de 2008.

FERREIRA, Aurélio Buarque de Holanda - Novo Dicionário de Língua Portuguesa - 2. ed. Ed. Nova Fronteira, 1998.

HODGSON, G.M. Institucional economics: surveying the "old" and the "new". Metroeconnômica, v. 44, n. 1, p. 1-28, 1993. crossrefhttp://dx.doi.org/10.1111/j.1467999X.1993.tb00786.x

HOLANDA. S. B. Raízes do Brasil. 26. ed. São Paulo: Companhia das Letras, 1995.

HUNT, E. K.; SHERMAN, H. J. História do Pensamento Econômico. 16. ed. Rio de Janeiro: Vozes, 1981.

FAORO, R. Os Donos do Poder: formação do patronato político brasileiro. 3. ed. São Paulo: Globo, 2001. 
MONASTÉRIO, L.M. Guia para Veblen: um estudo acerca da Economia Evolucionária. Pelotas: EDUFPEL, 1998.

Veblen e o comportamento humano: uma avaliação após um século de "A Teoria da Classe Ociosa".Cadernos IHU.Ano 3. n 42. 2005.

NOGUERÓL. L. P. Instituições da América Portuguesa: uma herança maldita? Texto para discussão. Disponível em 〈www.ufrgs.br/ppge>. Acesso em 10 de Fevereiro de 2008.

North, D. C. Institutions. Journal of Economic Perspectives, p 97-112, 1991.

Institutions, Institutional Change and Economic Performance. Cambridge: Cambridge University Press, 1995.

Desempeño econômico em el transcurso de los anos. Discurso de North ao receber o prêmio Nobel. Estocolmo, Suécia, dezembro de 1993. Disponível em <www.eumed.net.cursecon/textos/north-nobel.htm. Acesso 17 de fevereiro de 2009.

SUPREMO TRIBUNAL FEDERAL (STF). Súmula Vinculante $\mathbf{n}^{\circ}$ 13. Agosto de 2008. Disponível em <www.stf.jus.br. Acesso em 12 de Janeiro de 2008.

WEBER. M. Max Weber. Coleção Grandes Cientistas Sociais. coord. Florestan Fernandes. 7. ed. São Paulo: Atica, 2005.

WILLIAMSON, O.E. The Economics and transaction costs. New York: Free Press, 1999.

The new institucional econômics: taking stock, looking ahead. Journal of economic literature. Vol XXXVIII, p. 595-613, sept. 2000.

UnB. Universidade de Brasília. In: 50\% dos brasileiros toleram nepotismo. Disponível em <www.planejamento.gov.br. Acesso em 19 de fevereiro de 2009.

VEBLEN, T. B. A teoria da classe ociosa: um estudo econômico das instituições. São Paulo: Abril Cultural, 1983.

Recebido em 21.06.13

Aprovado em 31.10.14 